Dhaka Univ. J. Biol. Sci. 20(1): 49-56, 2011 (January)

\title{
PHYSIOLOGICAL CHARACTERS OF PSYCHROTOLERANT BACTERIA IN A EUTROPHIC BOTTOM ENVIRONMENT
}

\author{
MD. ABdul KARIM ${ }^{1}$ AND Kimio FuKAMI \\ Laboratory of Aquatic Environmental Science, Faculty of Agriculture, \\ Kochi University, Otsu 200 Monobe, Nankoku, Kochi 783-8502, Japan \\ Key words: Psychrotolerant bacteria, Eutrophic environment
}

\begin{abstract}
An investigation for the isolation and identification of psychrotolerant bacteria from eutrophic bottom environment showed average temperature during winter and summer was 8 and $26^{\circ} \mathrm{C}$, respectively. Six bacterial isolates were characterized in details and identified as Deleya halophila, Chromohalobacter marismortui, Erythrobacter longus, Pseudomonas perfectomarina, Marinobacter hydrocarbonoclasticus, Alteromonas undina. All isolates grew well at wide range of temperature between 5 and $30^{\circ} \mathrm{C}$ and considered as psychrotolerant.
\end{abstract}

\section{Introduction}

Intensive cage culture of yellow tail and red sea bream are widely practiced in eutrophic inlet, Kochi Prefecture, Japan. High nutrient inputs mostly in the form of high protein content food and fish juveniles were introduced to the fish farm since the aquaculture began. The small portion of the total nutrients input is recovered as the harvest of the cultured organisms, while a large portion of organic materials mainly in the form of excess feed, faeces and dissolved metabolites becomes the waste and is discharged into the environment without any treatment. ${ }^{(1)}$ An investigation estimated that the amount of added nitrogen and phosphorus to the intensive shrimp ponds through feed and fertilizers as being 95 and $71 \%$ of total amount of nitrogen and phosphorus in the natural environment, respectively, while harvested shrimp accounted for only $24 \%$ nitrogen and $13 \%$ phosphorus loaded into the pond.(2) This inlet is semienclosed and limited water exchange has led the eutrophication. ${ }^{(3)}$ Bottom environment of the inlet is which in organic matter and highly reduced especially in summer due to density stratification and microbial activities with oxygen-rich surface and oxygendeficient bottom environment. These imply heterotrophic activities at the study site are limited by dissolved oxygen (DO) concentration in summer (ca. $27^{\circ} \mathrm{C}$ ) and are limited in winter due to low temperature $\left(\mathrm{ca} .8^{\circ} \mathrm{C}\right)$, although $\mathrm{DO}$ concentration is sufficient, specially in bottom environment. ${ }^{(4)}$

${ }^{1}$ Corresponding author. Department of Botany, University of Dhaka, Dhaka-1000, Bangladesh. $<$ makarim10@yahoo.com>. 
The objectives of the present work were (i) isolation of bacteria that could be survived in a wide range of temperature, and (ii) identification of the selected isolates by their morphological and physiological characters.

\section{Materials and Methods}

Sampling site is a eutrophic area of the Uranouchi Inlet practicing intensive fish farming in cages. The average depth near the sampling point was 17-18 meter. Water samples were collected from bottom (16 $\mathrm{m}$ depth) environment and sediment samples were collected from surface sediment $(0-1 \mathrm{~cm}$ depth). Samples were carried back to the laboratory within 2-3 hours of sampling under cooling condition.

For isolation of bacteria bottom water and sediment samples were collected from the study site in December, 2000. One gram of wet sediment was added into $10 \mathrm{ml}$ filtersterilized (pore size $0.22 \mu \mathrm{m}$ ) bottom water. Then $1 \mathrm{ml}$ bottom water and $1 \mathrm{ml}$ sedimentwater suspension were inoculated into $10 \mathrm{ml}$ FeTY broth medium, separately and incubated at $4^{\circ} \mathrm{C}$. After one week, $1 \mathrm{ml}$ of bacterial culture was transferred from each test tube into new FeTY broth medium. It was continued until four times to enrich the psychrotolerant bacteria. FeTY agar medium was used for the enumeration and isolation of aerobic heterotrophic bacteria. The $\mathrm{pH}$ of the isolating medium was adjusted to 7.4 before sterilization. Two techniques, viz. serial dilution plate ${ }^{(5)}$ and spread plate $^{(6)}$ were used for the enumeration and isolation of bacteria. After enrichment of sufficient bacterial growth, $0.1 \mathrm{ml}$ of bacterial culture from each tube was taken and inoculated onto FeTY agar plates, and incubated at $4^{\circ} \mathrm{C}$. Initially, authors selected 100 colonies growing on FeTY agar plates and their colony morphology and cellular structure were studied. At the next, authors selected tentatively 6 bacterial strains W1, W2, W3, W4, S3A and S3B by fast growth rates and various colony morphologies.

Discrete bacterial colonies were isolated and sub-cultured immediately after selecting. Bacterial cells growing in FeTY broth medium () were conducted for 0, 6, 12, 18, $30,42,60$ and $72 \mathrm{hrs}$ of incubation at 5, 10, 15, 20, 25 and $30^{\circ} \mathrm{C}$. The growth curves of strain W1, W2, W3, W4, S3A and S3B were prepared by direct-count method using fluorescence DAPI (4, 6-diamidino-2-phenylindole dihydrochloride) stain.(8)

For provisional identification of selected isolates important biochemical tests were carried out, viz. catalase test, oxidase test, $\mathrm{Na}^{+}$ion requirement, indole production, citrate utilization, nitrate reduction test, Voges-Proskaur (VP) test, gelatin hydrolysis, methyl red test, carbohydrate fermentation, etc. Bergey's Manual of Determinative Bacteriology ${ }^{(9)}$

and Bergey's Manual of Systematic Bacteriology ${ }^{(10)}$ were followed for the identification of Gram-negative aerobic heterotrophic bacterial isolates. 


\section{Results and Discussion}

Initially 120 bacterial isolates were recovered from the eutrophic inlet at different seasons of the year. Out of these 6 isolates were selected on the basis of their colony characters, temperature effects and microscopic studies. Temperature dependent growth investigation was conducted with all selected isolates at the temperatures between 5 and $30^{\circ} \mathrm{C}$ and the results have been presented in Fig. 1. Bacterial isolates W1, W2 and W3 showed high growth rate both at low and high temperature of 10 and $30^{\circ} \mathrm{C}$. After counting of cell densities of isolate W1 in FeTY broth medium increased from $6.01 \times 10^{5}$ to $1.64 \times 10^{7}$ cells $/ \mathrm{ml}$ and $4.72 \times 10^{5}$ to $1.67 \times 10^{8}$ cells $/ \mathrm{ml}$ within $30 \mathrm{hrs}$ at 10 and $30^{\circ} \mathrm{C}$, respectively (Fig. 1A). Same trend of high growth yield both at low and high temperature was seen in the isolate W2 and W3 (Fig. 1B,C). During investigation of yield of W4, however, was seen more well at wide range of temperatures, between 5 and $30^{\circ} \mathrm{C}$. Cell densities of the isolate increased from $7.54 \times 10^{5}$ to $7.33 \times 10^{7}$ cells $/ \mathrm{ml}$ at $5^{\circ} \mathrm{C}$ and from 9.52 $\times 10^{5}$ to $2.95 \times 10^{8}$ cells $/ \mathrm{ml}$ at $30^{\circ} \mathrm{C}$ within $30 \mathrm{hrs}$ (Fig. 1D). The rest isolates S3A and S3B showed nearly same growth patterns of W1, W2, W3 and W4 (Fig. 1E,F).

For identification of the selected isolates morphological characteristics, such as cell shape, size, colony characteristics, pigmentation etc. were monitored. Different physiological characteristics, viz. Gram reaction, motility test, catalase test, oxidage test, $\mathrm{Na}^{+}$ion requirement, indole formation, citrate utilization, nitrate reduction, VogesProskauer test, gelatin hydrolysis, methyl red test, oxidation fermentation test, acid from D-glucose, L-arabinose and lactose were also monitored (Table 1).

All isolates were gram negative, motile and showed positive results in catalase, oxidase and citrate utilization test except $\mathrm{W} 2$ remarks negative in oxidase test. They were obligate aerobic, and able to grow on a mineral medium containing seawater base and $\mathrm{Na}^{+}$was an absolute requirement for growth. None of them could produce indole. In nitrate reduction test, except W3 and S3B, rest of the isolates showed positive results, however in gelatin hydrolysis test the results were vice versa viz. W3 and S3B showed positive and the rests were negative. Isolates W2, W4 and S3A showed positive in V.P. test, while, W1 and S3B showed positive in M.R test and others were shown negative both in V.P. and M.R. test. All isolates could produce acid after fermentation of three sugars viz. D-glucose, L-arabinose and lactose except S3B from D-glucose and W4 and S3A from lactose. Among all isolates only W4 could produce gas from D-glucose fermentation.

The selected 6 bacterial isolates were provisionally identified as Deleya halophila, Chromohalobacter marismortui, Erythrobacter longus, Pseudomonas perfectomarina, Marinobacter hydrocarbonoclasticus and Alteromonas undina (Fig. 1). 
Table 1. Physiological characteristics of the selected bacterial isolates recovered from eutrophic bottom environment of Uranouchi inlet of Kochi, Japan.

\begin{tabular}{|c|c|c|c|c|c|c|}
\hline \multirow[t]{2}{*}{ Parameter } & \multicolumn{6}{|c|}{ Bacterial isolates } \\
\hline & $\mathrm{W}-1$ & $\mathrm{~W}-2$ & $W-3$ & $W-4$ & S-3A & S-3B \\
\hline Gram reaction & - & - & - & - & - & - \\
\hline Cell shape & Short rod & Short rod & Long rod & Short rod & Short rod & Short rod \\
\hline Spore formation & $\begin{array}{l}\text { Non-spore } \\
\text { former }\end{array}$ & $\begin{array}{l}\text { Non-spore } \\
\text { former }\end{array}$ & $\begin{array}{l}\text { Non-spore } \\
\text { former }\end{array}$ & $\begin{array}{l}\text { Non-spore } \\
\text { former }\end{array}$ & $\begin{array}{l}\text { Non-spore } \\
\text { former }\end{array}$ & $\begin{array}{l}\text { Non-spore } \\
\text { former }\end{array}$ \\
\hline \multicolumn{7}{|l|}{ Colony: } \\
\hline Morphology & Circular & $\begin{array}{l}\text { Circular, } \\
\text { convex, } \\
\text { smooth }\end{array}$ & Circular & $\begin{array}{c}\text { Circular, } \\
\text { convex \& } \\
\text { smooth }\end{array}$ & Circular & Circular \\
\hline Colour & White & Brown & Orange & White & White & White \\
\hline $\begin{array}{l}\text { Motility in liquid } \\
\text { medium }\end{array}$ & Motile & Motile & Motile & Motile & Motile & Motile \\
\hline Pigment & - & + & + & - & - & - \\
\hline Aerobic & + & + & + & + & + & + \\
\hline Catalase & + & + & + & + & + & + \\
\hline Oxidase & + & - & + & + & + & + \\
\hline $\begin{array}{l}\text { Sea water or } \mathrm{Na}^{+} \\
\text {required for growth }\end{array}$ & + & + & + & + & + & + \\
\hline Indole production & - & - & - & - & - & - \\
\hline Citrate utilization & + & + & + & + & + & + \\
\hline Nitrate reduction & + & + & - & + & + & - \\
\hline Voges-Proskauer & - & + & - & + & + & - \\
\hline Gelatin hydrolysis & - & - & + & - & - & + \\
\hline Methyl red & + & - & - & - & - & + \\
\hline $\begin{array}{l}\text { Oxidation } \\
\text { fermentation }\end{array}$ & Oxidative & Oxidative & Oxidative & Oxidative & Oxidative & Oxidative \\
\hline \multicolumn{7}{|l|}{ Acid from: } \\
\hline D-glucose & + & + & + & $+($ Gas $)$ & + & - \\
\hline L-arabinose & + & + & + & + & + & + \\
\hline Lactose & + & + & + & - & - & + \\
\hline
\end{tabular}

' + ' indicate positive and ' - ' indicate negative results.

Deleya halophila was also isolated from hyper-saline soils. ${ }^{(1)}$ Characteristically, the isolate was aerobic, gram-negative rod and motile. It grew optimally in the presence of $7.5 \%(\mathrm{w} / \mathrm{v})$ marine salts. Several moderately halophilic isolates were recovered from a Mediterranean slattern showed that they were very closely related to Chromobacterium marismortui. (12) It was originally described on the basis of strains isolated from the dead sea, was not included on the approved lists of bacterial names and was not accepted as a member of the genus Chromobacterium since it produces a pigment that was not violacein. On the basis of the special features of the isolate, it was proposed that it should be placed 
in genus, Chromohalobacter, which includes a single species, Chromohalobacter marismortui. Several species of Chromohalobacter were also isolated from a Japanese salty food.(13)
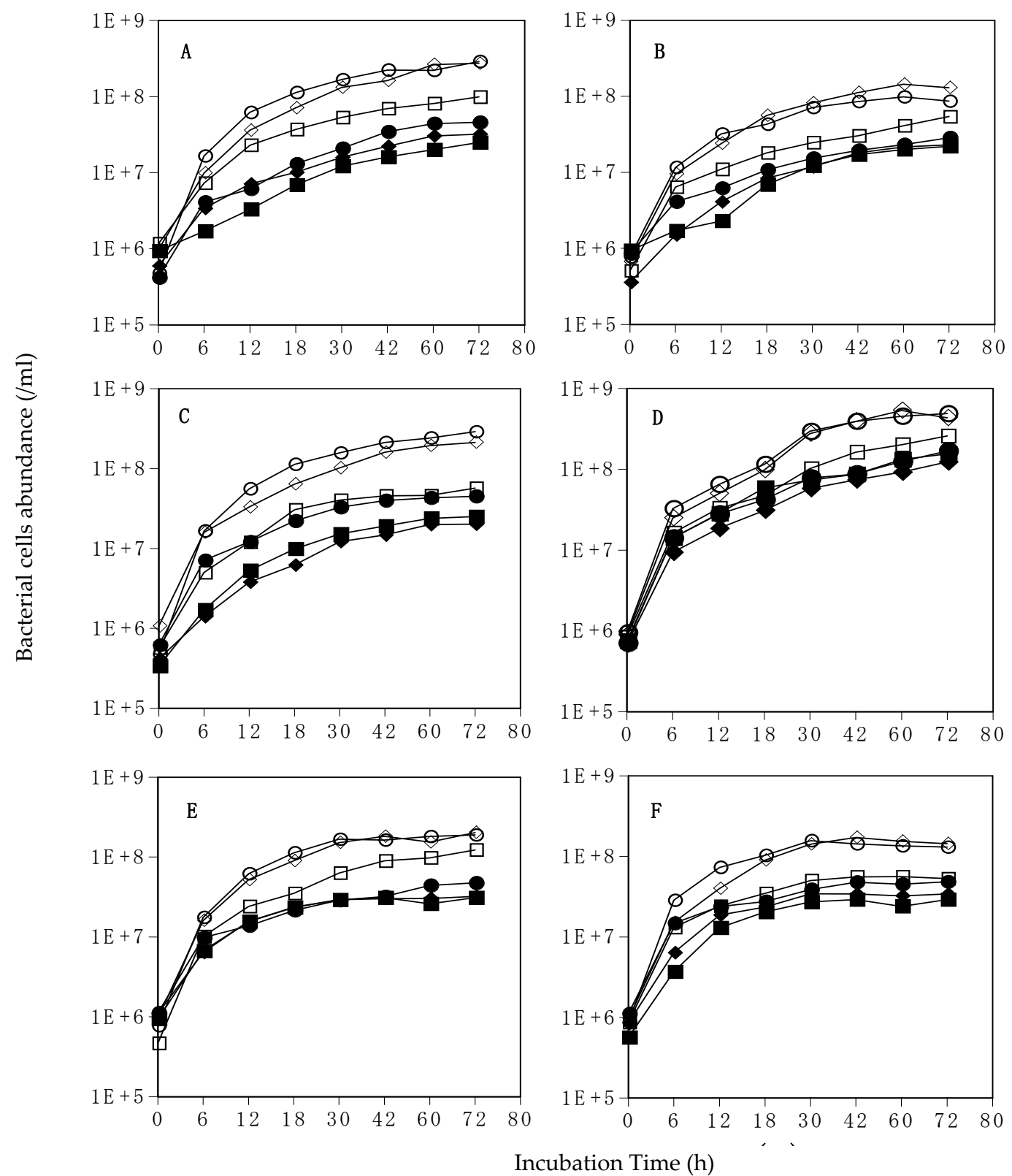

Fig. 1. Growth curve of different bacterial strains in FeTY broth medium at different temperatures between 5 and $30^{\circ} \mathrm{C} . \quad \mathrm{A}=$ Deleya halophila, $\mathrm{B}=$ Chromohalobacter marismortui, $\mathrm{C}=$ Erythrobacter longus, $\mathrm{D}=$ Pseudomonas perfectomarina, $\mathrm{E}=$ Marinobacter hydrocarbonoclasticus and $\mathrm{F}=$ Alteromonas undina. $5^{\circ} \mathrm{C}(---), 10^{\circ} \mathrm{C}(-\bullet-), 15^{\circ} \mathrm{C}(-\bullet-), 20^{\circ} \mathrm{C}(-\square-), 25^{\circ} \mathrm{C}(-\diamond-)$ and $30^{\circ} \mathrm{C}(-\mathrm{O}-)$. 
Some bacterial species were also recovered from different marine sources, such as Erythrobacter longus isolated from slightly halophilic environment. ${ }^{(14)}$ Few species of that were also isolated from soft coral of South China Sea ${ }^{(15)}$ and seawater of the Yellow Sea of Korea.(16) Pseudomonas perfectomarina was recovered from marine habitat.(17) Other two species, such as $P$. marincola and $P$. pohangensis were also isolated from a deep-sea brittle star in the Fiji Sea ${ }^{(18)}$ and seashore sand of Homi cape in Korea, respectively. ${ }^{(19)}$ Marinobacter hydrocarbonoclasticus was recovered from Mediterranean seawater.(20) However, other species of Marinobacter were found in seawater of the East Sea of Korea, ${ }^{(21)}$ sediment of the East Sea of China ${ }^{(22)}$ and sediment of the Chazhma Bay of Japan.(23) Two species of Alteromonas were also found separately from inter-tidal sediment in Korea ${ }^{(2)}$ and seawater of the East Sea in Korea.(25)

\section{Acknowledgements}

The authors are grateful to Professor Dr. T. Nishijima and Dr. M. Adachi for their valuable suggestions and help related to the study. Students of the laboratory of Aquatic Environmental Science (LAQUES) and the staff of the Marine Biological Research Center, Usa (Japan) helped during sampling and/or chemical or biological analysis for which the authors are thankful. The authors gratefully acknowledge the support in part by a Grantin-aid (Bio Renaissance Program) from the Ministry of Agriculture, Forestry and Fisheries (Japan) (BRP-98-II-B-1).

\section{References}

1. Kupka-Hansen P, K Pittman and A Ervik 1991. Organic waste from marine fish farms: effects on the seabed. In: Marine aquaculture and environment (Mäkinen T Ed.), Nord 22: 105-119.

2. Briggs MR and SJ Funge-Smith 1994. A nutrient budget of some intensive marine shrimp ponds in Thailand. Aquacult. Fish. Manage. 25: 789-811.

3. Fukami K, T Nishijima, H Murata, S Doi and Y Hata. 1991b. Distribution of bacteria influential on the development and the decay of Gymnodinium nagasakiense red tide and their effects on algal growth. Nippon Suisan Gakkaishi 57 : 2321-2328.

4. Patel AB, K Fukami and T Nishijima 2001. Extracellular proteolytic activity in the surface sediment of a eutrophic inlet. Microb. Environ. 16: 25-35.

5. Clesceri LS, AE Greenberg and AD Eaton 1998. Standard methods for examination of water and wastewater. APHA. Washington DC. Chapter 9, pp. 140.

6. Pepper IL, CP Gerba and JW Brendecke 1995. Environmental Microbiology: A Laboratory Manual. Academic Press Inc. California.

7. Fukami K, T Nishijima and Y Hata 1992. Availability of deep-sea water and effects of bacteria isolated from deep-sea water on the mass culture of food microflora Chaetoceros ceratosporum. Nippon Suisan Gakkashi. 58: 931-936.

8. Porter KG and YS Feig 1980. The use of DAPI for identifying and counting aquatic microflora. Limnol. Oceanogr. 25 : 943-948. 
9. Holt JG, NR Krieg, PHA Sneath, JT Staley and ST Williams 1994. Bergey's Manual of Determinative Bacteriology (9 $9^{\text {th }}$ edition). The Williams and Wilkins Company, Baltimore, Maryland. pp. 1-787.

10. Krieg NR and JG Holt 1984. Bergey's Manual of Systematic Bacteriology (Vol. 1). The Williams and Wilkins Company, Baltimore, Maryland. pp. 1-964.

11. Quesada E, A Ventosa, F Ruiz-Berraquero and A Ramos-Cormenzana 1984. Deleya halophila, a new species of moderately halophilic bacteria. Int. J. Syst. Bacteriol. 34: 287-292.

12. Ventosa A, MC Gutierrez, MT Garcia and F Ruiz-Berraquero 1989. Classification of "Chromobacterium marismortui" in a new genus, Chromohalobacter gen. nov., as Chromohalobacter marismortui comb. nov., nom. rev. Int. J. Stst. Bacteriol. 39: 382-386.

13. Sánchez-Porro C, H Tokunaga, M Tokunaga and A Ventosa 2007. Chromohalobacter japonicus sp. nov., a moderately halophilic bacterium isolated from a Japanese salty food. Int. J. Syst. Evol. Microbiol. 57: 2262-2266.

14. Rainey FA, J Silva, MF Nobre, MT Silva and MS da Costa 2003. Porphyrobacter cryptus sp. nov., a novel slightly thermophilic, aerobic, bacteriochlorophyll a-containing species. Int. J. Syst. Evol. Microbiol. 53: 35-41.

15. Ivanova EP, JP Bowman, AM Lysenko, NV Zhukova, NM Gorshkova, TA Kuznetsova, NI Kalinovskaya, LS Shevchenko and VV Mikhailov 2005. Erythrobacter vulgaris sp. nov., a novel organism isolated from the marine invertebrates. Syst. Appl. Microbiol. 28(2): 123130.

16. Yoon J-H, KH Kang, T-K Oh and Y-H Park 2004. Erythrobacter aquimaris sp. nov., isolated from sea water of a tidal flat of the Yellow Sea in Korea. Int. J. Syst. Evol. Microbiol. 54: 19811985.

17. Baumann P, RD Bowditch, L Baumann and B Beaman 1983. Taxonomy of marine Pseudomonas species: P. stanieri sp. nov.; P. perfectomarina sp. nov., nom. rev.; P. nautica: and $P$. doudoroffii. Int. J. Syst. Bacteriol. 33: 857-865.

18. Romanenko LA, M Uchino, BM Tebo, N Tanaka, GM Frolova and VV Mikhailov 2008. Pseudomonas marincola sp. nov., isolated from marine environments. Int. J. Syst. Evol. Microbiol. 58: 706-710.

19. Weon H-Y, B-Y Kim, S-H Yoo, Y-K Baek, S-Y Lee, S-W Kwon, S-J Go and E Stackebrandt 2006. Pseudomonas pohangensis sp. nov., isolated from seashore sand in Korea. Int. J. Syst. Evol. Microbiol. 56: 2153-2156.

20. Gauthier MJ, B Lafay, R Christen, L Fernandez, M Acquaviva, P Bonin and JC Bertrand 1992. Marinobacter hydrocarbonoclasticus gen. nov., sp. nov., a new, extremely halotolerant, hydrocarbon-degrading marine bacterium. Int. J. Syst. Bacteriol. 42: 568-576.

21. Roh SW, Z-X Quan, Y-D Nam, H-W Chang, K-H Kim, S-K Rhee, H-M Oh, CO Jeon, J-H Yoon and J-W Bae 2008. Marinobacter goseongensis sp. nov., from seawater. Int. J. Syst. Evol. Microbiol. 58: 2866-2870.

22. Huo Y-Y, C-S Wang, J-Y Yang, M Wu and X-W Xu 2008. Marinobacter mobilis sp. nov., and Marinobacter zhejiangensis sp. nov., halophilic bacteria isolated from the East China Sea. Int. J. Syst. Evol. Microbiol. 58: 2885-2889.

23. Gorshkova NM, EP Ivanova, AF Sergeev, NV Zhukova, Y Alexeeva, JP Wright, DV Nicolau, VV Mikhailov and R Christen 2003. Marinobacter excellens sp. nov., isolated from sediments of Sea of Japan. Int. J. Syst. Evol. Microbiol. 53: 2073-2078. 
24. Yoon J-H, S-H Yeo, T-K Oh and Y-H Park 2004. Alteromonas litorea sp. nov., a slightly halophilic bacterium isolated from an intertidal sediment of the Yellow Sea in Korea. Int. J. Syst. Evol. Microbiol. 54: 1197-1201.

25. Yoon J-H, I-G Kim, KH Kang, T-K Oh and Y-H Park 2003. Alteromonas marina sp. nov., isolated from sea water of the East Sea in Korea. Int. J. Syst. Evol. Microbiol. 53: 1625-1630.

(Manuscript received on 25 April, 2010; revised on 13 July, 2010) 